\title{
The effect of a mixture of Lactobacillus strains on silage quality and nutritive value of grass harvested at four growth stages and ensiled for two periods
}

\author{
Johan L. De Boever ${ }^{1^{*}}$, Elien Dupon², Eva Wambacq ${ }^{3}$ and Joos Latré ${ }^{2}$ \\ ${ }^{1}$ ILVO, Institute for Agricultural and Fisheries Research, Animal Sciences Unit, Scheldeweg 68, B-9090 Melle, Belgium, \\ ${ }^{2}$ University College Ghent, Faculty of Science and Technology, Experimental Farm Bottelare, Diepestraat 1, \\ B-9820 Merelbeke, Belgium, \\ ${ }^{3}$ University College Ghent, Associated Faculty of Applied Bioscience Engineering, Valentijn Vaerwyckweg 1, \\ B-9000 Ghent, Belgium \\ e-mail: johan.deboever@ilvo.vlaanderen.be
}

\begin{abstract}
The effect of adding an inoculant containing Lactobacillus buchneri, L. plantarum and L. casei to wilted perennial ryegrass, harvested at four growth stages and ensiled for either 60 or $150 \mathrm{~d}$ on silage fermentation quality, chemical composition, rumen degradability of neutral detergent fibre (NDF) and organic matter (OM) and in vitro OM digestibility (OMd) was studied. Compared to the control silage, more sugars were fermented to lactic and acetic acid with the inoculant, resulting in a lower $\mathrm{pH}$, less dry matter losses and protein degradation and a better aerobic stability. The effects of the additive on fermentation quality were more pronounced after 150 than after $60 \mathrm{~d}$ of ensiling, because the quality of the control silage was worse after the long ensiling period. The treatment lowered NDF content of grass harvested at the first two growth stages by degrading cell walls to complex sugars, but had no effect on NDF degradability of the silage. The inoculant had no effect on rumen OM degradability nor on OMd after the short ensiling period, but increased the rumen OM degradability for the first two growth stages and OMd for all growth stages after the long ensiling period.
\end{abstract}

Key words: cell wall degradability, ferulate esterase, Lactobacillus, grass silage

\section{Introduction}

Grass silage is an important component in the ration of cattle especially during the winter time. The quality of grass silage depends to a large extent on the growth stage of the grass at harvest, the weather conditions during field wilting and the ensiling practices. In case of unfavourable ensiling conditions, silage additives may be used. Currently mostly inoculants containing living micro-organisms are used. Recently an inoculant for ensiling grass was introduced with the aim to improve not only silage fermentation quality and aerobic stability, but also to enhance digestibility and nutritive value of the silage. This so-called multipurpose inoculant consists of three Lactobacillus strains: L. plantarum, L. casei and L. buchneri. The former two strains are facultative heterofermentative, whereas the latter is strict heterofermentative (Holzer et al. 2003). The production of acetic acid besides lactic acid explains the improvement of aerobic stability, observed with the use of L. buchneri (Kung and Ranjit 2001). Moreover, L. buchneri is able to produce ferulate esterase (FE), an enzyme which breaks down the linkages between (hemi)cellulose and lignin (Donaghy et al. 1998).

The objective of this study was to examine if the above-mentioned aims are reached by investigating the effects of the inoculant on the fermentation characteristics, the chemical composition, the in situ rumen degradability and in vitro digestibility of grass silage. Although it is recommended to mow grass not too late for making good quality silage, the efficacy of the inoculant was studied at four growth stages. It would answer the question if the claimed positive effect of the additive on digestibility offers farmers more flexibility to postpone harvest in case of bad weather conditions or to obtain higher grass yields. The effect of inoculant additive was studied after 60 and 150 days of ensiling to examine if a long ensiling period could have an additional effect compared to a more common ensiling period. This additional effect is expected as $L$. buchneri is known as a slowly growing bacterium (Schmidt et al. 2009). 


\section{Material and methods}

The grass used in the experiment originated from a parcel perennial ryegrass (Lolium perenne) sown in April 2008, which received $120 \mathrm{~kg} \mathrm{~N} \mathrm{ha}^{-1}$ in March 2010. The first cut of the grass was weekly harvested between the end of April and early June 2010. Then, 4 stages were selected for further study based on distinct contents of NDF. At each harvest a representative batch of about $150 \mathrm{~kg}$ grass was mown with a Haldrup harvester (Inotec, Løgstør, Denmark) around $1100 \mathrm{~h}$. Dry matter (DM) yield was estimated from the fresh weight of the harvested area and the DM-content of the grass. Then, grass was wilted on the field to obtain a DM-content of about $35 \%$. Wilting lasted for $25,29,73$ and $24 \mathrm{~h}$, respectively; the longer wilting period after the third harvest was because of rain on the second day. Subsequently, the grass was cut with a field chopper (Sperry New Holland, Zedelgem, Belgium) set at a theoretical length of $24 \mathrm{~mm}$. Samples of the wilted grass were taken, dried in a ventilated oven at $65^{\circ} \mathrm{C}$, ground to pass a 1-mm screen and analysed for residual moisture, neutral detergent fibre (NDF) and sugar content. NDF was determined with the filter bag method using $\alpha$-amylase and sodium sulphite (Van Soest et al. 1991). Sugars were extracted with $40 \%$ ethanol (EC 1971a).

The wilted grass was ensiled in cylindrical plastic tubes with a volume of 2.75 I (height $35 \mathrm{~cm}$, diameter $10 \mathrm{~cm}$ )

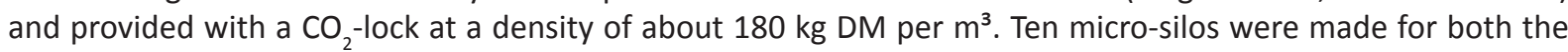
control and the treatment. For making the treated silos, $20 \mathrm{~kg}$ wilted grass spread on a plastic sheet was sprayed with $0.2 \mathrm{I}$ of distilled water in which $20 \mathrm{mg}$ of inoculant additive was dissolved (recommended dose: $1 \mathrm{~g}$ per ton wilted grass) and thoroughly mixed. The studied inoculant Pioneer ${ }^{\circledR} 11 \mathrm{GFT}$ is a commercial product (Pioneer Hibred Northern Europe) containing the strains L. buchneri LN40177, L. plantarum LP24011 and L. casei LC32909 at concentrations of $>1.0 \times 10^{11},>2.0 \times 10^{10}$ and $>1.0 \times 10^{10} \mathrm{cfu}$ per $\mathrm{g}$ product, respectively. Before filling the control silos, 0.2 I distilled water was added to another $20 \mathrm{~kg}$ of wilted grass. The number of lactic acid bacteria (LAB) in the inoculant as well as in the control and inoculated silage material was counted according to ISO 15214 (1998). The filled micro-silos were stored at ambient temperature in an enclosed barn. Half of the tubes were ensiled for $60 \mathrm{~d}$, the other half for $150 \mathrm{~d}$.

Micro-silos were weighed weekly to determine fermentation losses. Eighteen days before opening, aerobic stress was induced to all micro-silos by removing the tape from openings at the bottom and top of the tubes during 24 h. At the opening of the silos, 4 out of 5 tubes were selected for further study by eliminating the micro-silo with visible most mould growth. The remaining tubes were individually sampled to determine silage quality. Aerobic stability was measured according to Honig (1990) for a maximum of $170 \mathrm{~h}$ and expressed as the time in hours until temperature of silage raised $3{ }^{\circ} \mathrm{C}$ above ambient temperature. To determine fermentation characteristics an extract was made by soaking $100 \mathrm{~g}$ of silage in 1 I distilled water at $4{ }^{\circ} \mathrm{C}$ during $16 \mathrm{~h}$. On the extract $\mathrm{pH}$, ammonia-N (Kjeldahl without previous destruction, ISO 5983-2 2005), lactic acid (Noll 1966, Gawehn 1984), acetic acid, propionic acid, butyric acid and alcohols with gas chromatography (Jouany 1981) were determined.

The effect of additive on rumen degradability of NDF and OM was studied on 3 out of 4 randomly selected micro-silos per control/treatment. Also, DM, crude ash and NDF were analysed on each micro-silo. The DM-content was determined by drying a sample in a ventilated oven at $65^{\circ} \mathrm{C}$ and analysis of residual moisture in a ground subsample by drying at $103^{\circ} \mathrm{C}$ during $4 \mathrm{~h}$ (EC 1971b). Crude ash content was obtained by incineration at $550^{\circ} \mathrm{C}$ (ISO 5984, 2002). The rumen degradation characteristics of OM and NDF were determined by means of the nylon bag technique. Therefore, bags $(8 \times 10 \mathrm{~cm}$, pore size $37 \mu \mathrm{m})$ were filled with 2.5/5.0 g DM-equivalent of frozen and finely cut silage (particles $\leq 10 \mathrm{~mm}$ ) and incubated in two rumen-cannulated cows for $8,24,48,72$ and 336 $\mathrm{h}$ (a two-fold sample weight was used for the two long incubation times). Per time four bags, two per cow, were incubated. Besides, 3 bags were filled with sample but underwent no rumen incubation to determine the washout fraction (W). The lactating cows received a basal ration consisting of maize and grass silage (50/50 on DM-basis) supplemented with concentrates. After incubation, bags with residues were rinsed under running tap water, frozen, machine-washed (Zanussi, Frankfurt/Main, Germany) with cold water for 50 min without spin cycle and freeze dried. Residues were pooled per incubation time and ground to pass a 1-mm screen. Incubation residues were analyzed for residual moisture, crude ash and NDF. The potentially degradable fraction (D) was calculated as $100-\mathrm{W}-\mathrm{U}$, with $\mathrm{U}$ being the undegradable fraction after $336 \mathrm{~h}$ of incubation. 
The degradation rate $(k d)$ of $D$ was derived by iteration using the exponential model $d(t)=W+D \times\left(1-e^{(-k d x t)}\right)$ with $d(t)$ the disappearance at time $t$ ( $\varnothing$ rskov and McDonald 1979). Then, the rumen fermentable NDF fraction (FNDF) was calculated as:

FNDF $(\%)=D_{\mathrm{NDF}} \times\left[\mathrm{kd}_{\mathrm{NDF}} /\left(\mathrm{kd}_{\mathrm{NDF}}+\mathrm{kp}_{\mathrm{NDF}}\right)\right]$

with $\mathrm{kp}_{\mathrm{NDF}}$ being the passage rate of NDF derived from the equation: $\mathrm{kp}_{\mathrm{NDF}}=0.1775 \times \mathrm{kd}_{\mathrm{NDF}}+1.39$ and assuming $\mathrm{W}_{\mathrm{NDF}}=0$ (Tamminga et al. 2007).

The rumen fermentable OM (FOM) fraction was calculated as:

$\operatorname{FOM}(\%)=\mathrm{W}_{\mathrm{OM}}+\mathrm{D}_{\mathrm{OM}} \times\left[\left(\mathrm{kd}_{\mathrm{OM}} /\left(\mathrm{kd}_{\mathrm{OM}}+\mathrm{kp}_{\mathrm{OM}}\right)\right]\right.$

with $\mathrm{kp}_{\mathrm{OM}}$ the passage rate of OM, equaling $4.5 \% \mathrm{~h}^{-1}$ (Tamminga et al. 2007).

Finally, the remaining material of the 3 micro-silos was pooled per treatment, dried and ground to pass a 1-mm screen. Crude protein (CP; ISO 5983-2, 2005), sugars and crude fat (ISO 6492, 1999) were determined and total OM digestibility (OMd) was estimated by an in vitro cellulase technique (De Boever et al. 1986). The content of residual non starch polysaccharides (RNSP), as a measure of pectins and complex sugars like arabans, xylans and beta-glucans (Tamminga et al. 2007) was calculated as:

RNSP = 1000 - NDF - CP - crude ash - sugars - crude fat - FP

with FP being the silage fermentation products calculated as the sum of lactic, acetic, propionic and butyric acid as well as the alcohols.

The DM-content and chemical composition were corrected for losses of volatile substances according to Dulphy and Demarquilly (1981).

Statistical analysis was carried out by means of SAS for Windows version 9.3. The normality for the repetitions within control/treatment was examined according to Kolmogorov-Smirnov. If normal, an ANOVA was done to investigate the effect of the additive treatment and the interaction between additive treatment and growth stage; control and treatment means within growth stage and ensiling period were compared by a t-test. If not normal, a non-parametric Kruskall-Wallis analysis was carried out to investigate the effect of treatment and to compare control and treatment means; this was only the case for $\mathrm{pH}$ after 60 and $150 \mathrm{~d}$ and for butyric acid content after $150 \mathrm{~d}$. For the parameters determined on a pooled silage sample, $C P$, sugars, crude fat and OMD as well as the sum of the fermentation products and RNSP, the overall effect of treatment was examined across the 4 growth stages within ensiling period using ANOVA.

\section{Results}

From the first to the last harvest date DM-yield increased from 3100 to $5100 \mathrm{~kg}$ and NDF content from 365 to 535 $\mathrm{g} \mathrm{kg}^{-1} \mathrm{DM}$ (Table 1). Sugar content varied in the range of $150 \mathrm{~g} \mathrm{~kg}^{-1} \mathrm{DM}$ at the third growth stage to $225 \mathrm{~g} \mathrm{~kg}^{-1} \mathrm{DM}$ at the first growth stage.

Table 1. Dry matter yield and chemical composition of grass harvested at 4 growth stages

\begin{tabular}{lcccc}
\hline Harvest date & $\begin{array}{c}\text { Yield } \\
\left(\mathrm{kg} \mathrm{DM}^{\mathrm{a}} \mathrm{ha}^{-1}\right)\end{array}$ & $\begin{array}{c}\mathrm{DM} \\
\left(\mathrm{g} \mathrm{kg}^{-1}\right)\end{array}$ & $\begin{array}{c}\mathrm{NDF}^{\mathrm{b}} \\
\left(\mathrm{g} \mathrm{kg}^{-1} \mathrm{DM}\right)\end{array}$ & $\begin{array}{c}\text { Sugars } \\
\left(\mathrm{g} \mathrm{kg}^{-1} \mathrm{DM}\right)\end{array}$ \\
\hline 28 April 2010 & 3100 & 364 & 365 & 225 \\
17 May 2010 & 3450 & 336 & 422 & 184 \\
25 May 2010 & 4010 & 365 & 505 & 150 \\
2 June 2010 & 5100 & 360 & 535 & 201 \\
\hline
\end{tabular}

a dry matter

${ }^{\mathrm{b}}$ neutral detergent fibre 
The number of LAB in the applied product amounted to $1.3 \times 10^{10} \mathrm{cfu} \mathrm{g}^{-1}$, which was somewhat lower than the number mentioned on the label $\left(1.1 \times 10^{11} \mathrm{cfu} \mathrm{g}^{-1}\right)$. Following the recommendation of the manufacturer $1.3 \times$ $10^{4} \mathrm{cfu}$ was effectively added per $\mathrm{kg}$ of wilted grass. Compared to the control silage addition of the inoculant increased the number (cfu g ${ }^{-1}$ wilted grass) of lactic acid bacteria (ISO 15214) from $6.0 \times 10^{2}$ to $3.2 \times 10^{4}$ at the first stage, from $4.8 \times 10^{2}$ to $3.0 \times 10^{4}$ at the second, from $2.0 \times 10^{3}$ to $1.5 \times 10^{4}$ at the third and from $<10$ to $1.2 \times 10^{4}$ at the last growth stage.

\section{Chemical composition and in vitro OM digestibility}

The DM-content of the control silage either after $60 \mathrm{~d}$ or $150 \mathrm{~d}$ of ensiling (Table 2) corresponded fairly well with that of the wilted grass at ensiling (Table 1). The addition of the inoculant significantly $(p \leq 0.01)$ increased DMcontent at all stages and for both ensiling periods. The increase was most pronounced for stages 1 and 2 after both 60 and $150 \mathrm{~d}$ of ensiling.

Compared with the grass at ensiling, the NDF content of the control silages after both 60 and $150 \mathrm{~d}$ of ensiling was somewhat lower. Treatment with the inoculant significantly $(p \leq 0.01)$ decreased NDF content at the first two growth stages after $60 \mathrm{~d}$ of ensiling and the first three stages after the long ensiling period.

The ash content of the control silage was significantly $(p \leq 0.05)$ higher than that of the treated silages. The difference was smallest at the last growth stage.

The protein content of the control silage decreased with later harvesting from $238 \mathrm{~g} \mathrm{~kg}^{-1} \mathrm{DM}$ for stage 1 to 132 $\mathrm{g} \mathrm{kg}^{-1} \mathrm{DM}$ for stage 4. Treated silages had a lower CP content than the control silages; averaged over the four growth stages the difference amounted to 4 and $10 \mathrm{~g} \mathrm{~kg}^{-1} \mathrm{DM}$ for periods of 60 and $150 \mathrm{~d}$ of ensiling, respectively, but significantly $(p \leq 0.05)$ only after $60 \mathrm{~d}$.

The sugar content of the control silage after $60 \mathrm{~d}$ was clearly lower compared with that of the grass at ensiling except for stage 2; longer ensiling further decreased sugar content. All treated silages had a lower sugar content than the control silage. Averaged over the four growth stages the sugar content of the control and treated silages after the $60 \mathrm{~d}$ of ensiling amounted to 95 and $35 \mathrm{~g} \mathrm{~kg}^{-1} \mathrm{DM}$, respectively, and after the $150 \mathrm{~d}$ of ensiling to 45 and $23 \mathrm{~kg}^{-1} \mathrm{DM}$, respectively. The difference was significant $(p \leq 0.05)$ only for the short ensiling period.

The content of fermentation products (FP) of the control silage after $60 \mathrm{~d}$ varied between $78 \mathrm{~g} \mathrm{~kg}^{-1} \mathrm{DM}$ at stage 2 to $98 \mathrm{~g} \mathrm{~kg}^{-1} \mathrm{DM}$ at stage 4. Longer ensiling further increased FP for stages 1 and 2. Compared with the control silage, the inoculant significantly increased FP content from 91 to $125 \mathrm{~g} \mathrm{~kg}^{-1}$ DM after $60 \mathrm{~d}$ and from 103 to 131 $\mathrm{g} \mathrm{kg}^{-1} \mathrm{DM}$ after $150 \mathrm{~d}$.

Crude fat content of all silages varied between 38 and $49 \mathrm{~g} \mathrm{~kg}^{-1} \mathrm{DM}$ and was not affected by the treatment.

The content of RNSP tended to increase with later harvesting and longer ensiling. The inoculant increased the RNSP content in all cases, except for the fourth growth stage after $150 \mathrm{~d}$ of ensiling. Averaged over the four growth stages the RNSP content of the control and treated silage after the $60 \mathrm{~d}$ of ensiling amounted to 77 and $124 \mathrm{~g} \mathrm{~kg}^{-1}$ $\mathrm{DM}$, respectively, and after the $150 \mathrm{~d}$ of ensiling to 102 and $124 \mathrm{~kg}^{-1} \mathrm{DM}$, respectively. The difference was significant $(p \leq 0.05)$ only after the short ensiling period.

The cellulase OM digestibility of the control silage (averaged for the two ensiling periods) decreased gradually from $91.3 \%$ at growth stage 1 to $73.4 \%$ at growth stage 4 . The OMd was always higher with the inoculant than with the control, except at growth stage 2 after $60 \mathrm{~d}$ of ensiling. The mean OMd for the four growth stages of the control and the treated silage after $60 \mathrm{~d}$ of ensiling amounted to 82.6 and $83.6 \%$, respectively, and after $150 \mathrm{~d}$ of ensiling to 81.6 and $83.9 \%$, respectively. The difference was significant $(p \leq 0.05)$ only after the long ensiling period. 
Table 2. The effect of the inoculant (control C versus treatment $\mathrm{T}$ ) on the chemical composition and in vitro OMd of grass harvested at 4 growth stages and after an ensiling period (EP) of either 60 or $150 \mathrm{~d}$ (means of 3 micro-silos for DM, NDF and crude ash; single values for the other parameters).

\begin{tabular}{|c|c|c|c|c|c|c|c|c|c|c|c|c|}
\hline & \multirow{2}{*}{$\begin{array}{l}\text { EP } \\
\text { (d) }\end{array}$} & \multicolumn{2}{|c|}{ Stage 1} & \multicolumn{2}{|c|}{ Stage 2} & \multicolumn{2}{|c|}{ Stage 3} & \multicolumn{2}{|c|}{ Stage 4} & \multirow[t]{2}{*}{ SEM $^{\mathrm{e}}$} & \multirow[t]{2}{*}{$T^{f}$} & \multirow[t]{2}{*}{ TxS } \\
\hline & & $\mathrm{C}$ & $\mathrm{T}$ & $\mathrm{C}$ & $\mathrm{T}$ & C & $\mathrm{T}$ & $\mathrm{C}$ & $\mathrm{T}$ & & & \\
\hline Dry matter & 60 & 387 & $397 * *$ & 342 & $362 * *$ & 370 & $380 * *$ & 359 & $365^{* *}$ & 2.9 & $* *$ & $* *$ \\
\hline$\left(\mathrm{g} \mathrm{kg}^{-1}\right)$ & 150 & 378 & $404 * *$ & 334 & $356 * *$ & 367 & $375^{* *}$ & 352 & $358^{*}$ & 3.5 & $* *$ & $* *$ \\
\hline NDFa $^{a}$ & 60 & 344 & $317 * *$ & 397 & $377 * *$ & 491 & $484^{\mathrm{ns}}$ & 513 & $506^{\mathrm{ns}}$ & 15.3 & $* *$ & $* *$ \\
\hline ( $\left.\mathrm{g} \mathrm{kg}^{-1} \mathrm{DM}\right)$ & 150 & 344 & $313 * *$ & 410 & $379 * *$ & 492 & $483 *$ & 504 & $514^{\mathrm{ns}}$ & 15.3 & $* *$ & $* *$ \\
\hline Crude ash & 60 & 111 & $108^{*}$ & 94 & $86^{* *}$ & 81 & $75^{* *}$ & 81 & $78^{\text {ns }}$ & 2.7 & $* *$ & $* *$ \\
\hline ( $\left.\mathrm{g} \mathrm{kg}^{-1} \mathrm{DM}\right)$ & 150 & 117 & $110^{* *}$ & 97 & $87^{* *}$ & 82 & $78^{* *}$ & 80 & $79 *$ & 2.9 & $* *$ & $* *$ \\
\hline Crude protein & 60 & 231 & 226 & 169 & 167 & 141 & 138 & 135 & 129 & 13.5 & $*$ & nd \\
\hline$\left(\mathrm{g} \mathrm{kg}^{-1} \mathrm{DM}\right)$ & 150 & 245 & 225 & 186 & 167 & 144 & 142 & 129 & 129 & 14.7 & ns & nd \\
\hline Sugars & 60 & 119 & 70 & 153 & 38 & 58 & 17 & 52 & 14 & 16.1 & $*$ & nd \\
\hline ( $\left.\mathrm{g} \mathrm{kg}^{-1} \mathrm{DM}\right)$ & 150 & 48 & 47 & 65 & 26 & 36 & 10 & 32 & 9 & 6.3 & ns & nd \\
\hline $\mathrm{FP}^{\mathrm{b}}$ & 60 & 96 & 132 & 78 & 136 & 91 & 120 & 98 & 112 & 6.8 & $*$ & nd \\
\hline$\left(\mathrm{g} \mathrm{kg}^{-1} \mathrm{DM}\right)$ & 150 & 118 & 141 & 108 & 143 & 93 & 120 & 94 & 120 & 6.3 & $* *$ & nd \\
\hline Crude fat & 60 & 41 & 46 & 41 & 46 & 39 & 38 & 41 & 41 & 1.0 & ns & nd \\
\hline$\left(\mathrm{g} \mathrm{kg}^{-1} \mathrm{DM}\right)$ & 150 & 45 & 49 & 46 & 47 & 40 & 43 & 41 & 44 & 1.0 & ns & nd \\
\hline RNSPc & 60 & 57 & 101 & 70 & 149 & 100 & 127 & 82 & 120 & 10.2 & $*$ & nd \\
\hline$\left(\mathrm{g} \mathrm{kg}^{-1} \mathrm{DM}\right)$ & 150 & 83 & 115 & 88 & 150 & 115 & 124 & 120 & 105 & 7.0 & ns & nd \\
\hline $\mathrm{OMd}^{\mathrm{d}}$ & 60 & 91.8 & 92.4 & 88.8 & 88.1 & 76.9 & 79.1 & 73.1 & 74.6 & 2.64 & ns & nd \\
\hline (\%) & 150 & 90.7 & 93.0 & 86.8 & 88.6 & 75.2 & 79.0 & 73.6 & 74.9 & 2.61 & $*$ & nd \\
\hline
\end{tabular}

${ }^{a}$ neutral detergent fibre

${ }^{\mathrm{b}}$ fermentation products

c residual non starch polysaccharides

${ }^{d}$ in vitro cellulase digestibility of the OM

e: standard error of the mean

f: significance of treatment effect

g: significance of interaction between treatment $(\mathrm{T})$ and growth stage $(\mathrm{S})$

ns: not significant $(p>0.05),{ }^{*}$ significant at $p \leq 0.05,{ }^{* *}$ significant at $p \leq 0.01$

nd: the interaction treatment $x$ growth stage could not be determined because of limited degrees of freedom

\section{Silage fermentation quality}

The weekly DM-losses of all micro-silos increased linearly $(p \leq 0.01)$ from week 1 to the opening of the silos after both 60 and $150 \mathrm{~d}$ of ensiling. For the control silages of $60 \mathrm{~d}$ ensiling losses increased gradually up to 6 weeks after ensiling but with a steeper slope after the induction of aerobic stress (Fig. 1). The losses were higher with advancing harvest stage. Initially, treated silages had higher DM-losses than control silages, the difference being significant ( $p \leq 0.05)$ up to weeks 4, 4, 3 and 2 after ensiling for stages 1, 2, 3 and 4, respectively. With longer ensiling, DM-losses for treated silages were no longer different $(p>0.05)$ from control silages and became even smaller $(p \leq 0.05)$ after 8,7 and 4 weeks for stages 1, 3 and 4, respectively. 


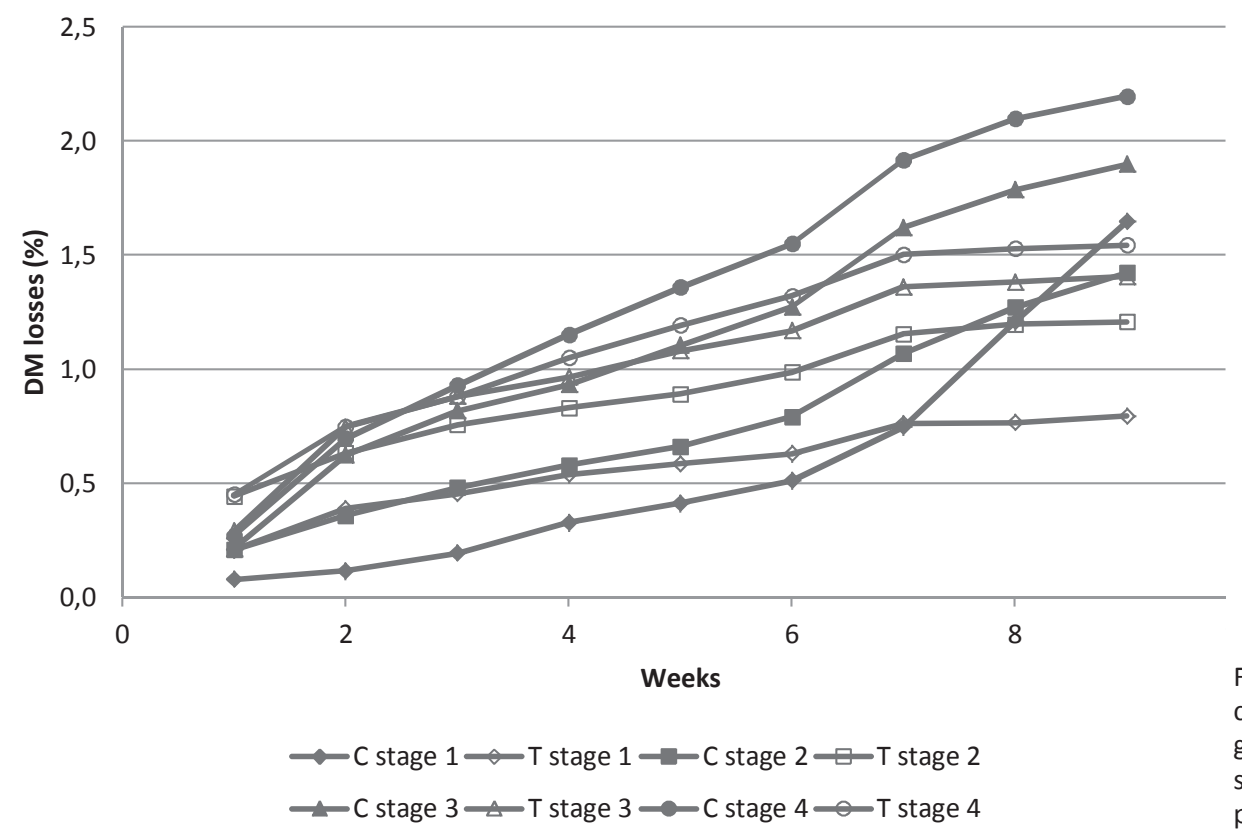

Fig. 1. Weekly DM-losses of control (C) and treated ( $\mathrm{T}$ ) grass silage at four growth stages during a 60 d ensiling period.

The DM-losses of the control silages ensiled for $150 \mathrm{~d}$ (Fig. 2) increased gradually for stages 3 and 4, whereas losses for stages 1 and 2 showed a steep increase after about 8 weeks and were higher than those of the later stages at the opening of the silos. Initially, treated silages had higher DM-losses than control silages, the difference being significant ( $p \leq 0.01$ ) up to weeks 3, 3, 2 and 1 after ensiling for stages 1, 2, 3 and 4, respectively. With longer ensiling, DM-losses for treated silages were no longer different $(p>0.05)$ from control silages and became even smaller ( $p \leq 0.01$ ) after 12,12, 7 and 6 weeks for stages 1, 2, 3 and 4, respectively.

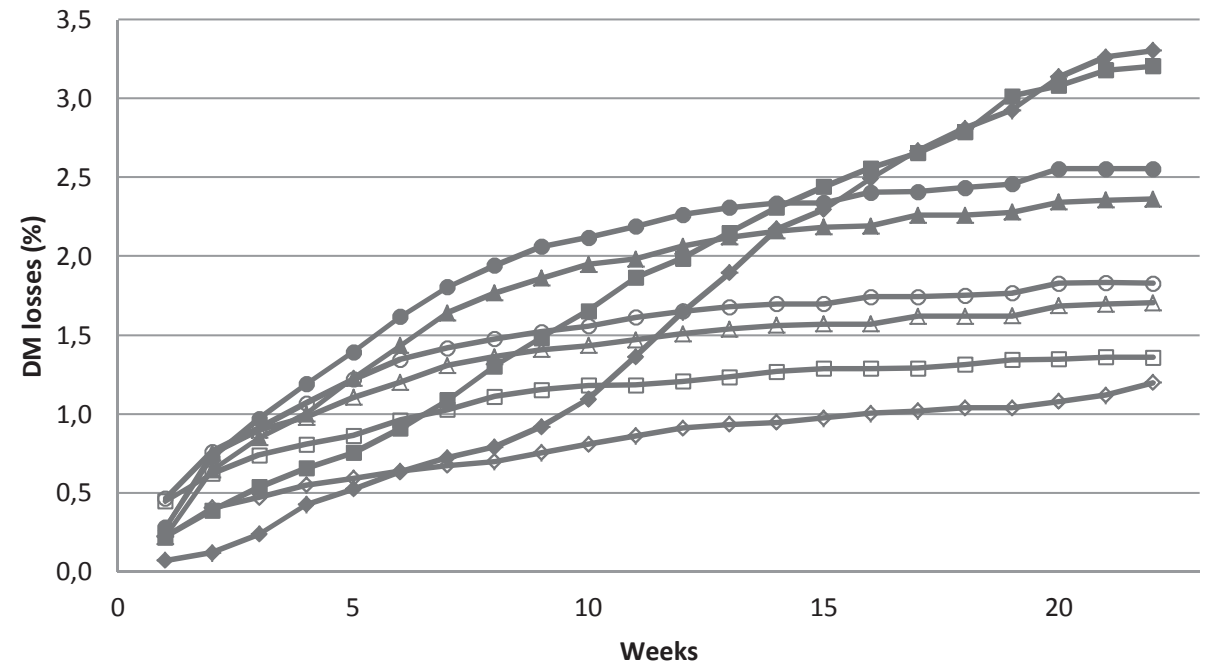

$\multimap C$ stage $1 \leadsto T$ stage $1 \backsim C$ stage $2 \curvearrowleft T$ stage 2

$\longrightarrow$ C stage $3 \multimap$ T stage $3 \longrightarrow C$ stage $4 \multimap$ T stage 4
Fig. 2. Weekly DM-losses of control (C) and treated ( $\mathrm{T}$ ) grass silage at four growth stages during a $150 \mathrm{~d}$ ensiling period.

The final weight loss of the control silages after $60 \mathrm{~d}$ of ensiling varied from $1.4 \%$ for growth stage 2 to $2.2 \%$ for growth stage 4 (Table 3). Longer ensiling increased weight losses particularly for growth stages 1 and 2, when losses more than doubled. The inoculant significantly $(p \leq 0.01)$ decreased losses, the effect being significant for stages 1, 3 and 4 after $60 \mathrm{~d}$ of ensiling and for all stages after the long ensiling period. 
Table 3. The effect of the inoculant (control $\mathrm{C}$ versus treatment $\mathrm{T}$ ) on silage quality of grass harvested at 4 growth stages and after an ensiling period (EP) of either 60 or $150 \mathrm{~d}$ (means of 4 micro-silos).

\begin{tabular}{|c|c|c|c|c|c|c|c|c|c|c|c|c|}
\hline & \multirow{2}{*}{$\begin{array}{l}\text { EP } \\
\text { (d) }\end{array}$} & \multicolumn{2}{|c|}{ Stage 1} & \multicolumn{2}{|c|}{ Stage 2} & \multicolumn{2}{|c|}{ Stage 3} & \multicolumn{2}{|c|}{ Stage 4} & \multirow[t]{2}{*}{ SEM $^{a}$} & \multirow[t]{2}{*}{$\mathrm{T}^{\mathrm{b}}$} & \multirow[t]{2}{*}{$\mathrm{TxS}^{\mathrm{c}}$} \\
\hline & & C & $T$ & C & $\mathrm{T}$ & C & $\mathrm{T}$ & C & $\mathrm{T}$ & & & \\
\hline $\begin{array}{l}\text { Final } \\
\text { weight }\end{array}$ & 60 & 1.6 & $0.8^{* *}$ & 1.4 & $1.2^{\mathrm{ns}}$ & 1.9 & $1.4^{* *}$ & 2.2 & $1.5^{* *}$ & 0.08 & $* *$ & $* *$ \\
\hline loss (\%) & 150 & 3.3 & $1.2^{* *}$ & 3.2 & $1.4^{* *}$ & 2.4 & $1.7^{* *}$ & 2.6 & $1.8^{* *}$ & 0.14 & $* *$ & $* *$ \\
\hline \multirow[t]{2}{*}{$\mathrm{pH}$} & 60 & 4.93 & $3.93 * *$ & 4.60 & $3.84^{* *}$ & 4.41 & $3.93^{* *}$ & 4.42 & $4.04^{* *}$ & 0.066 & $* *$ & nd \\
\hline & 150 & 5.92 & $3.95 * *$ & 5.07 & $3.85^{* *}$ & 4.62 & $4.01^{* *}$ & 4.82 & $4.07 * *$ & 0.121 & $* *$ & nd \\
\hline $\begin{array}{l}\text { Lactic } \\
\text { acid }\end{array}$ & 60 & 32 & $87^{* *}$ & 40 & $83^{* *}$ & 46 & $71^{* *}$ & 45 & $52^{\mathrm{ns}}$ & 3.5 & $* *$ & $* *$ \\
\hline $\begin{array}{l}\left(\mathrm{g} \mathrm{kg}^{-1}\right. \\
\mathrm{DM})\end{array}$ & 150 & 29 & $89 *$ & 26 & $87^{* *}$ & 34 & $65^{* *}$ & 33 & $55^{* *}$ & 4.5 & $* *$ & $* *$ \\
\hline $\begin{array}{l}\text { Acetic } \\
\text { acid }\end{array}$ & 60 & 26 & $24^{\text {ns }}$ & 11 & $32 * *$ & 11 & $27 * *$ & 11 & $34^{* *}$ & 1.6 & $* *$ & $* *$ \\
\hline $\begin{array}{l}\left(\mathrm{g} \mathrm{kg}^{-1}\right. \\
\mathrm{DM})\end{array}$ & 150 & 16 & $29 * *$ & 8 & $33 * *$ & 16 & $29 * *$ & 10 & $40 * *$ & 2.0 & $* *$ & $* *$ \\
\hline $\begin{array}{l}\text { Butyric } \\
\text { acid }\end{array}$ & 60 & 0.0 & 0.0 & 0.0 & 0.0 & 0.0 & 0.0 & 0.0 & 0.0 & 0.00 & ns & ns \\
\hline $\begin{array}{l}\left(\mathrm{g} \mathrm{kg}^{-1}\right. \\
\mathrm{DM})\end{array}$ & 150 & 0.0 & $0.0^{\text {ns }}$ & 0.0 & $0.0^{\text {ns }}$ & 2.3 & $0.0^{*}$ & 3.3 & $0.1 * *$ & 0.26 & $* *$ & nd \\
\hline Alcohols & 60 & 38 & $21^{* *}$ & 27 & $21^{*}$ & 34 & $22^{* *}$ & 42 & $26^{* *}$ & 1.4 & $* *$ & $* *$ \\
\hline $\begin{array}{l}\left(\mathrm{g} \mathrm{kg}^{-1}\right. \\
\mathrm{DM})\end{array}$ & 150 & 73 & $24 * *$ & 74 & $24 * *$ & 41 & $26^{* *}$ & 48 & $25^{* *}$ & 3.7 & $* *$ & $* *$ \\
\hline $\mathrm{NH}_{3}-\mathrm{N} / \mathrm{N}$ & 60 & 4.5 & $2.7^{* *}$ & 6.3 & $3.8^{* *}$ & 7.6 & $6.3^{* *}$ & 8.3 & $5.5^{* *}$ & 0.32 & $* *$ & $* *$ \\
\hline (\%) & 150 & 4.8 & $3.6^{* *}$ & 6.7 & $4.5^{* *}$ & 7.1 & $6.4^{* *}$ & 8.6 & $6.0 * *$ & 0.27 & $* *$ & $* *$ \\
\hline $\begin{array}{l}\text { Aerobic } \\
\text { stability }\end{array}$ & 60 & 30 & $127^{*}$ & 24 & $153^{* *}$ & 31 & $150 * *$ & 32 & $>170^{* *}$ & 12.0 & $* *$ & ns \\
\hline$(h)^{d}$ & 150 & 94 & $>170 * *$ & 43 & $>170^{* *}$ & 76 & $>170 * *$ & 39 & $>170 * *$ & 12.8 & $* *$ & $* *$ \\
\hline
\end{tabular}

${ }^{a}$ standard error of the mean

${ }^{\mathrm{b}}$ significance of treatment effect

${ }^{\mathrm{c}}$ significance of interaction between treatment $(\mathrm{T})$ and growth stage $(\mathrm{S})$

d aerobic stability was measured for a maximum of $170 \mathrm{~h}$

ns: not significant $(p>0.05),{ }^{*}$ significant at $p \leq 0.05, * *$ significant at $p \leq 0.01$

nd: not determined because of non-parametric Kruskall-Wallis analysis

The $\mathrm{pH}$ of the control silage after $60 \mathrm{~d}$ of ensiling varied between 4.41 for stage 3 to 4.93 for stage 1. Longer ensiling increased $\mathrm{pH}$ with 0.2 to 1.0 units; the greatest increase was observed for stage 1 . Treating grass significantly $(p \leq 0.01)$ decreased $\mathrm{pH}$ at all stages and for both ensiling periods. The effect varied from 0.4 to 2.0 units and was most pronounced for the long ensiling period. The difference decreased with later harvest date.

Lactic acid content of the control silage after $60 \mathrm{~d}$ varied between $32 \mathrm{~g} \mathrm{~kg}^{-1} \mathrm{DM}$ for stage 1 to $46 \mathrm{~g} \mathrm{~kg}^{-1} \mathrm{DM}$ for stage 3 and was lower at each stage after $150 \mathrm{~d}$ of ensiling. The inoculant significantly $(p \leq 0.01)$ increased lactic acid content for both ensiling periods. The effect clearly decreased with later harvest date. 
Acetic acid content of the control grass silage after $60 \mathrm{~d}$ varied between $11 \mathrm{~g} \mathrm{~kg}^{-1}$ DM for stages 2,3 and 4 to $26 \mathrm{~g}$ $\mathrm{kg}^{-1} \mathrm{DM}$ for stage 1 . Longer ensiling decreased the content for stage 1 and increased the content for stage 3 . The addition of the inoculant significantly $(p \leq 0.01)$ increased acetic acid content for both ensiling periods. For stage 1 after $60 \mathrm{~d}$ of ensiling no difference was observed.

Butyric acid was not detected in the control nor in the treated silages after $60 \mathrm{~d}$. After $150 \mathrm{~d}$ of ensiling butyric acid was present in the control silage of stages 3 and 4 , but not in the treated silages.

Propionic acid was not detected in any of the control or treated silages.

The total alcohol content of the control silages after $60 \mathrm{~d}$ varied from $27 \mathrm{~g} \mathrm{~kg}^{-1} \mathrm{DM}$ for stage 2 to $42 \mathrm{~g} \mathrm{~kg}^{-1} \mathrm{DM}$ for stage 4. Longer ensiling increased alcohol content, particularly for stages 1 and 2 . Treatment significantly $(p \leq 0.01)$ lowered alcohol content; the decrease was most pronounced for stages 1 and 2 after long ensiling.

The ammonia fraction of the control silage after $60 \mathrm{~d}$ increased gradually with later harvesting from $4.5 \%$ for stage 1 to $8.3 \%$ for stage 4 . Longer ensiling increased the ammonia fraction a little more except for stage 3 when a small decrease was observed. Treatment with the inoculant significantly $(p \leq 0.01)$ decreased the ammonia fraction for all stages and both ensiling periods with 0.7 to $2.8 \%$-units.

Aerobic stability of the control silage after $60 \mathrm{~d}$ was fairly constant among stages amounting to about $30 \mathrm{~h}$. Longer ensiling increased aerobic stability in all stages. Treatment with the inoculant significantly $(p \leq 0.01)$ improved aerobic stability. After $150 \mathrm{~d}$ of ensiling, the silage with the inoculant remained stable at all stages for more than $7 \mathrm{~d}$.

\section{Rumen degradability of NDF and OM}

The potentially degradable fraction as well as the degradation rate of NDF in the rumen decreased with later harvest date (Table 4). As a result, the rumen fermentable NDF fraction decreased from $67.6 \%$ for the first stage to $52.5 \%$ for the last stage. The inoculant had no effect on $D_{N D F}$ nor on $k_{N D F}$ of the grass silage after $60 \mathrm{~d}$. On the other hand after $150 \mathrm{~d}$ of ensiling, treatment increased $D_{\mathrm{NDF}}$, the effect being significant $(p \leq 0.01)$ at stages 2 and 4 , whereas it decreased $\mathrm{kd}_{\mathrm{NDF}}$, but the difference was only significant $(p \leq 0.01)$ at stage 2 . Treatment had no effect on the rumen degradable NDF fraction at all growth stages and for the two ensiling periods.

Later harvesting decreased the washable OM fraction and the degradation rate of OM and had no clear effect on the potentially degradable OM fraction. As a result the rumen fermentable OM fraction averaged for both ensiling periods decreased from $74.8 \%$ for the first stage to $56.5 \%$ for the last stage. Treatment did not affect any of the degradation characteristics after $60 \mathrm{~d}$ of ensiling. On the other hand after longer ensiling, treatment significantly $\left(p \leq 0.05\right.$ ) increased $W_{O M}$ at stages 1 and 2 , had no effect on $D_{O M}$ and decreased $\mathrm{kd}_{\mathrm{OM}}$, but only significantly $(p \leq 0.05)$ at the last stage after $150 \mathrm{~d}$. As a result, treatment had no effect on FOM\% after $60 \mathrm{~d}$ of ensiling, whereas it increased \%FOM at stages 1 and 2 after $150 \mathrm{~d}$ of ensiling. 
Table 4. The effect of the inoculant (control $\mathrm{C}$ versus treatment $\mathrm{T}$ ) on rumen degradation characteristics of NDF and OM of grass harvested at 4 growth stages and after an ensiling period (EP) of either 60 or $150 \mathrm{~d}$ (means of 3 micro-silos)

\begin{tabular}{|c|c|c|c|c|c|c|c|c|c|c|c|c|}
\hline & \multirow{2}{*}{$\begin{array}{l}E P \\
\text { (d) }\end{array}$} & \multicolumn{2}{|c|}{ Stage 1} & \multicolumn{2}{|c|}{ Stage 2} & \multicolumn{2}{|c|}{ Stage 3} & \multicolumn{2}{|c|}{ Stage 4} & \multirow[t]{2}{*}{$\mathrm{SEM}^{\mathrm{h}}$} & \multirow[t]{2}{*}{$\mathrm{T}^{\mathrm{i}}$} & \multirow[t]{2}{*}{ TxS } \\
\hline & & C & $\mathrm{T}$ & C & $\mathrm{T}$ & C & $\mathrm{T}$ & C & $\mathrm{T}$ & & & \\
\hline $\mathrm{D}_{\mathrm{NDF}}^{\mathrm{a}}$ & 60 & 92.9 & 90.4 & 87.7 & 86.6 & 81.9 & 82.1 & 78.2 & 76.0 & 1.21 & ns & ns \\
\hline (\%) & 150 & 89.5 & $91.2^{\mathrm{ns}}$ & 86.9 & $89.7^{* *}$ & 81.8 & $82.9^{\text {ns }}$ & 77.6 & $81.6 * *$ & 0.96 & $* *$ & ns \\
\hline$k d_{N D F}^{b}$ & 60 & 6.87 & 6.63 & 6.51 & 5.74 & 3.81 & 4.06 & 4.34 & 4.34 & 0.257 & ns & ns \\
\hline$\left(\% h^{-1}\right)$ & 150 & 7.76 & $7.31^{\mathrm{ns}}$ & 6.36 & $5.50 * *$ & 4.47 & $4.18^{\mathrm{ns}}$ & 4.70 & $4.36^{\mathrm{ns}}$ & 0.282 & $* *$ & ns \\
\hline FNDF $^{c}$ & 60 & 67.3 & 65.2 & 63.0 & 61.0 & 53.1 & 53.9 & 52.2 & 50.7 & 1.30 & ns & ns \\
\hline (\%) & 150 & 65.9 & $66.7^{\mathrm{ns}}$ & 62.3 & $62.7^{\mathrm{ns}}$ & 54.9 & $54.9^{\text {ns }}$ & 52.7 & $54.5^{\mathrm{ns}}$ & 1.11 & $*$ & ns \\
\hline$W_{O M}{ }^{d}$ & 60 & 43.6 & 44.9 & 41.6 & 39.8 & 30.2 & 30.3 & 28.7 & 27.5 & 1.43 & ns & * \\
\hline (\%) & 150 & 40.6 & $46.0 * *$ & 36.5 & $40.2^{* *}$ & 31.1 & $30.1^{\mathrm{ns}}$ & 29.2 & $28.1^{\mathrm{ns}}$ & 1.29 & $* *$ & $* *$ \\
\hline$D_{O M}{ }^{e}$ & 60 & 51.1 & 48.9 & 47.3 & 49.4 & 54.6 & 54.9 & 53.2 & 52.6 & 0.58 & ns & * \\
\hline (\%) & 150 & 50.4 & 48.3 & 52.4 & 51.5 & 53.9 & 56.1 & 52.6 & 56.1 & 0.55 & ns & $* *$ \\
\hline $\mathrm{kd}_{\mathrm{OM}}{ }^{\mathrm{f}}$ & 60 & 7.45 & 7.79 & 7.35 & 7.17 & 4.22 & 4.58 & 4.72 & 5.17 & 0.302 & ns & ns \\
\hline$\left(\% h^{-1}\right)$ & 150 & 8.96 & $8.49^{n s}$ & 7.10 & $6.45^{\text {ns }}$ & 4.78 & $4.56^{\mathrm{ns}}$ & 5.11 & $4.69 *$ & 0.356 & $*$ & ns \\
\hline FOM $^{\mathrm{g}}$ & 60 & 75.4 & 75.9 & 70.9 & 70.2 & 56.5 & 57.9 & 55.9 & 55.6 & 1.79 & ns & ns \\
\hline (\%) & 150 & 74.1 & $77.5^{*}$ & 68.5 & $70.5^{*}$ & 58.8 & $58.4^{\text {ns }}$ & 57.1 & $56.7^{\text {ns }}$ & 1.65 & $* *$ & $* *$ \\
\hline
\end{tabular}

a potentially degradable NDF fraction

${ }^{b}$ degradation rate of $D_{N D F}$

${ }^{\mathrm{c}}$ rumen fermentable NDF

${ }^{\mathrm{d}}$ washable OM fraction

e potentially degradable OM fraction

${ }^{f}$ degradation rate of $D_{O M}$

g rumen fermentable OM

${ }^{\mathrm{h}}$ standard error of the mean

i significance of treatment effect

j significance of interaction between treatment $(\mathrm{T})$ and growth stage $(\mathrm{S})$

ns: not significant $(p>0.05), *$ significant at $p \leq 0.05, * *$ significant at $p \leq 0.01$

\section{Discussion \\ Control silage}

The effect of the inoculant was studied with a first cut grass harvested at four distinct growth stages. The evolution in growth stage was clearly reflected by the increase in NDF content (from 344 to $509 \mathrm{~g} \mathrm{~kg}^{-1} \mathrm{DM}$ ) and the decrease in CP content (from 238 to $132 \mathrm{~g} \mathrm{~kg}^{-1} \mathrm{DM}$ ) as well as in $\mathrm{OMd}$ (from 91.3 to $73.4 \%$ ) of the control silage. The growth stage had not only an effect on the quantity of NDF but also on its quality. From the rumen degradation characteristics of NDF it appeared that later harvesting resulted in an increase of the undegradable fraction from about $10 \%$ at the first stage to more than $20 \%$ at the last stage and means a decreasing potentially degradable fraction. Moreover, the degradation rate of the latter almost halved in the period from the first to the last growth stage. Later harvesting also increased the rumen undegradable OM fraction, whereas the potentially degradable $\mathrm{OM}$ fraction remained almost constant because of the decrease of the washable OM fraction. This later tendency can be explained by the decrease of sugars and of soluble protein in silage of a later growth stage.

The inoculant was applied to grass wilted at a DM content of about $35 \%$. Wilting grass is already a good measure to improve silage quality because epiphytic lactic acid bacteria are relatively more tolerant to low moisture availability than the vegetative forms of undesirable clostridia (Woolford 1984). According to the latter there is no more 
advantage to wilt further than 300-340 $\mathrm{g} \mathrm{DM} \mathrm{kg}^{-1}$, because from then on oxidation could increase losses. Indeed the control silage of all 4 stages after $60 \mathrm{~d}$ of ensiling showed small DM-losses (1.6 to 2.2\%), a low pH (4.4 to 4.9$)$, no butyric acid and a low ammonia fraction (4.5 to 8.3\%). Despite the proper fermentation characteristics, aerobic stability of the control silage at all stages was low (about $30 \mathrm{~h}$ ), considering that the target for potential aerobic stability is $7 \mathrm{~d}$ (Wilkinson and Davies 2013).

For testing the efficacy of silage additives, EFSA (2006) recommends an ensiling period of $90 \mathrm{~d}$ or longer. In this study a shorter period of $60 \mathrm{~d}$ was chosen, because it is a common practice that farmers open their silo after 2 months of ensiling in the assumption that silage fermentation is finished. However, comparison of the control silages after 60 and $150 \mathrm{~d}$ of ensiling in the present study showed worse quality after longer ensiling at all stages. Compared with $60 \mathrm{~d}$ of ensiling, longer ensiling resulted in higher DM-losses (2.4 to 3.3\%), a lower DM content, a higher $\mathrm{pH}$, particularly for the first growth stage, a reduced lactic acid content and an increased alcohol content and the presence of butyric acid at stages 3 and 4 . These changes were accompanied by a further decrease of sugar content and indicate that the fermentation process was still ungoing after $60 \mathrm{~d}$ of ensiling. Considering the low aerobic stability observed after $60 \mathrm{~d}$ of ensiling, the oxidation of the control silages during longer ensiling may have been caused by some air ingression through the tape covering the openings in the tube. Another explanation is the higher risk for aerobic deterioration at a density of $180 \mathrm{~kg} \mathrm{DM} \mathrm{per} \mathrm{m}^{3}$, as applied in our experiment. Such a density also prevails in practice, but is lower than the recommended minimum density of $210 \mathrm{~kg}$ DM per $\mathrm{m}^{3}$ (Wilkinson and Davies 2013).

\section{The effect of the inoculant on chemical composition and silage quality}

The number of LAB counted in the inoculated grass silage corresponded fairly well with the number added with the inoculant, whereas the number in the control silages was low to very low. Notwithstanding the proper quality of the control silage after $60 \mathrm{~d}$ of ensiling, treatment clearly improved almost all fermentation characteristics. The inoculant decreased weight losses, resulting in a higher DM content of the silage. It increased lactic acid content; the effect was most pronounced for the first two harvest dates. It also increased acetic acid content at all stages except the first. The increase in the production of acids was reflected in a decrease of $\mathrm{pH}$. On the other hand, the addition of the inoculant decreased the formation of alcohols, which is an indication that yeasts and moulds were inhibited, which is also reflected by the better aerobic stability of the treated silage. That the inoculant reduced the activity of undesirable organisms appears also from the lower ammonia fraction, meaning less protein degradation in the silo. Similar effects by inoculating wilted perennial ryegrass $\left(330 \mathrm{~g} \mathrm{DM} \mathrm{kg}^{-1}\right)$ with $L$. buchneri plus a mixture of Pediococcus pentosaceus and L. plantarum on $\mathrm{pH}$, lactic acid, the ammonia fraction, DM loss and aerobic stability were observed by Driehuis et al. (2001).

The production of more acetic acid besides more lactic acid proves the activity of the heterofermentative bacterium L. buchneri in the inoculant. Acetic acid inhibits yeasts and moulds, which was clearly reflected by the lower alcohol production and better aerobic stability. The higher acid production by the added living Lactobacilli was possible through the fermentation of more sugars. The addition of the inoculant also lowered NDF content of the silage, particularly at the early growth stages. The decrease of NDF content is interesting for the nutritive value of the silage as it should result in a higher feed intake. Indeed, cell wall content highly affects feed intake by contributing to rumen fill (Jung and Allen 1995).

The decrease in NDF content was accompanied by an increase of RNSP content, a measure of complex sugars. This is another indication of the activity of L. buchneri, which was shown to produce ferulate esterase (Donaghy et al. 1998). This enzyme seems able to attack young cell walls, but not lignified ones.

The improvement of silage quality by addition of the inoculant was even more pronounced after $150 \mathrm{~d}$ of ensiling. This greater effect is rather due to the worse quality of the untreated silage after $150 \mathrm{~d}$ of ensiling than to a prolonged effect of the inoculant. The lower contents of CP and crude ash in the DM of the treated grass silage at all stages after both ensiling periods, although small, may be explained by a dilution effect. Indeed, when expressed per $\mathrm{kg}$ of silage, $\mathrm{CP}$ and ash contents were similar for the control and the treated silage. 


\section{The effect of the inoculant on NDF and OM degradability}

Because of the presence of $L$. buchneri, which is able to produce ferulate esterase (FE), the studied inoculant is claimed to improve the nutritive value of the resulting grass silage through a better cell wall degradability in the rumen. Weinberg et al. (2004) have shown that lactic acid bacteria consumed with silage enter the rumen and may survive there. Nsereko et al. (2008) examined the activity of 8 FE producing Lactobacilli by in situ incubations and found that they all increased $48 \mathrm{~h}$ rumen NDF degradability of perennial ryegrass by 9 to $11 \%$. The studied strains did not affect NDF content of the silage and one strain increased NDF content, whereas we found a decrease of NDF content in the treated silage of growth stages 1 and 2. In their study however, the control grass silage contained $571 \mathrm{~g} \mathrm{NDF} \mathrm{kg}^{-1} \mathrm{DM}$, which is even more than the cell wall content of the last stage in our study. Thus, it agrees with our finding that the inoculant has no effect on cell wall content in silage from older grass. But also Driehuis et al. (2003) found no effect of $L$. buchneri, with or without homofermentative lactic acid bacteria, on NDF content of perennial ryegrass with $438 \mathrm{~g} \mathrm{NDF} \mathrm{kg}^{-1} \mathrm{DM}$, similar to that of the second growth stage in our experiment. In agreement with our results, Van Vuuren et al. (1989) found a decrease of NDF content when herbage was treated with cell wall degrading enzymes; the effect decreased with increasing maturity and DM content of the grass.

In contrast with Nsereko et al. (2008), who found an increase of NDF degradability with the same L. buchneri strain as present in the inoculant of our study, we did not find an effect of treatment on the rumen fermentable NDF fraction at any of the growth stages either after 60 or $150 \mathrm{~d}$ of ensiling. Considering the clear positive effects on silage fermentation quality, particularly the increase in acetic acid and the better aerobic stability, one may conclude that L. buchneri has worked in our experiment. Moreover, it seems that L. buchneri has developed FE activity during the ensiling process by degrading easily degradable cell walls, and so leaving cell walls which were more difficult to degrade in the rumen. Similar observations were done by Van Vuuren et al. (1989) treating herbage with cell wall degrading enzymes.

The percentage of rumen FOM is another interesting nutritive parameter because it determines microbial protein production. The inoculant had no effect on \%FOM at any growth stage after $60 \mathrm{~d}$ of ensiling, but increased $\%$ FOM of the silage from the first and second growth stage after $150 \mathrm{~d}$ of ensiling. This increase was mainly due to a higher $\mathrm{W}_{\mathrm{OM}}$ fraction, which can be explained by the increase in fermentation products as well as complex sugars. The treatment effects for rumen FOM are confirmed by those for in vitro OM digestibility. The latter mimics digestibility over the whole digestive tract and treatment increased OMd after $150 \mathrm{~d}$ of ensiling with on average $2.3 \%$-units over the four growth stages.

\section{Conclusions}

By treating wilted grass with the inoculant more sugars were fermented to lactic and acetic acid, resulting in a lower $\mathrm{pH}$, less DM-losses and protein degradation and a better aerobic stability. The effects on silage quality were more pronounced after $150 \mathrm{~d}$ of ensiling than after $60 \mathrm{~d}$, but this was rather due to the worse quality of the control silage than to a prolonged effect of the inoculant. Although wilting grass is a good measure to obtain good quality silage, quality can still further be improved by using the inoculant.

The treatment lowered NDF content of grass harvested at the early growth stages, probably by degrading NDF to complex sugars but had no effect on NDF degradability in the rumen. The inoculant improved rumen fermentability as well as in vitro digestibility of OM after $150 \mathrm{~d}$ of ensiling. Postponing harvest and correcting the nutritive value of the silage by applying inoculant additive seems however no option.

\section{Acknowledgements}

The authors highly appreciate Dr.ir. A. De Vliegher from the Plant Sciences Unit of ILVO for caring and harvesting the grass parcel. 


\section{References}

De Boever, J.L., Cottyn, B.G., Buysse, F.X., Wainman, F.W. \& Vanacker, J.M. 1986. The use of an enzymatic technique to predict digestibility, metabolizable and net energy of compound feedstuffs for ruminants. Animal Feed Science and Technology 14: 203-214.

Donaghy, J., Kelly, P.F., McKay, A.M. 1998. Detection of ferulic acid esterase production by Bacillus spp. and Lactobacilli. Applied Microbiology and Biotechnology 50: 257-260.

Driehuis, F., Oude Elferink, S.J.W.H. \& Van Wikselaar, P.G. 2001. Fermentation characteristics and aerobic stability of grass silage inoculated with Lactobacillus buchneri, with or without homofermentative lactic acid bacteria. Grass and Forage Science 56: 330-343.

Dulphy, J.P. \& Demarquilly C. 1981. Correction de la teneur en matière sèche des ensilages. In: Prévision de la valeur nutritive des aliments des ruminants. INRA Publications, Versailles, France. p. 91-96. (in French).

EC 1971a. Determination of sugar. Comission directive 71/250/EEC establishing Community methods of analysis for the official control of feedingstuffs. Official Journal of the European Communities L155, 12 July 1971. p. 13.

EC 1971b. Determination of moisture. Comission directive 71/393/EEC establishing Community methods of analysis for the official control of feedingstuffs. Official Journal of the European Communities L279, 20 December 1971. p. 7.

EFSA 2006. Opinion of the scientific panel on additives and products or substances used in animal feed for the establishment of guidelines on the assessment of safety and efficacy of silage additives, on a request from the Commission under article 7(5) of regulation (EC) $n^{\circ}$ 1831/2003. The EFSA Journal 349: 1-10.

Gawehn, K. 1984. D-(-)-Lactate. In: Bergmeyer, H.U. (ed.). Methods of Enzymatic Analysis. Third ed., vol. VI , Weinheim, Germany: Verlag Chemie. p. 588-592.

Holzer, M., Mayrhuber, E., Danner, H. \& Braun, R. 2003. The role of Lactobacillus buchneri in forage preservation. Trends in Biotechnology 21: 282-287.

Honig, H. 1990. Evaluation of aerobic stability. In: Lingvall, P. \& Lindgren, S. (eds.). Proc. of the Eurobac. Conf. 12-16 August 1986. Swed. Univ. of Agric. Sci. Grass and Forage Report No. 3-1990, Uppsala, Sweden. p. 76-81.

ISO 15214, 1998. Microbiology of food and animal feeding stuffs - Horizontal method for the enumeration of mesophilic lactic acid bacteria. International Standards Organization, Geneva, Switzerland. 7 p.

ISO 6492, 1999. Animal feeding stuffs - Determination of fat content. International Standards Organization, Geneva, Switzerland. 9 p. ISO 5984, 2002. Animal feeding stuffs - Determination of crude ash. International Standards Organization, Geneva, Switzerland. 6 p.

ISO 5983-2, 2005. Animal feeding stuffs - Determination of nitrogen content and calculation of crude protein content - Part 2: Block digestion/steam distillation method. International Standards Organization, Geneva, Switzerland. 14 p.

Jouany, J.P. 1981. Dosage des acides gras volatils et des alcools dans les ensilages par chromatographie en phase gazeuse. Bulletin Technique C.R.Z.V. Theix, INRA, 46: 63-66. (in French).

Jung, H.G. \& Allen, 1995. Characteristics of plant cell walls affecting intake and digestibility of forages by ruminants. Journal of Animal Science 73: 2774-2790.

Kung, L. Jr. \& Ranjit, N.K. 2001. The effect of Lactobacillus buchneri and other additives on the fermentation and aerobic stability of barley silage. Journal of Dairy Science 84: 1149-1155.

Noll, F. 1966. Methode zur quantitativen Bestimmung van L(+)-Lactat mittels Lactat-Dehydrogenase und Glutamat-Pyruvat-Transaminase. Biochemischen Zeitschrift 346: 41-49. (in German).

Nsereko, V.L., Smiley, B.K., Rutherford, W.M., Spielbauer, A., Forrester, K.J., Hettinger, G.H., Harman, E.K. \& Harman, B.R. 2008. Influence of inoculating forage with lactic acid bacterial strains that produce ferulate esterase on ensilage and ruminal degradation of fiber. Animal Feed Science and Technology 145: 122-135.

$\emptyset$ rskov, E.R. \& McDonald, I. 1979. The estimation of protein degradability in the rumen from incubation measurements weighted according to rate of passage. Journal of Agricultural Science (Cambridge) 92: 499-503.

Schmidt, R.J., Hu, W., Mills, J.A. \& Kung Jr., L. 2009. The development of lactic acid bacteria and Lactobacillus buchneri and their effects on the fermentation of alfalfa silage. Journal of Dairy Science 92: 5005-5010.

Tamminga, S., Brandsma, G.G., Dijkstra, J., Van Duinkerken, G., Van Vuuren, A.M. \& Blok, M.C. 2007. Protein evaluation in ruminants: The DVE/OEB 2007 system. CVB Documentation report nr. 53, Centraal Veevoederbureau, Lelystad, The Netherlands. 58 p.

Van Soest, P.J., Robertson, J.B. \& Lewis, B.A. 1991. Methods for dietary fiber, neutral detergent fiber, and nonstarch polysaccharides in relation to animal nutrition. Journal of Dairy Science 74: 3583-3597.

Van Vuuren, A.M., Bergsma, K., Frol-Kramer, F. \& Van Beers, J.A.C. 1989. Effects of addition of cell wall degrading enzymes on the chemical composition and the in sacco degradation of grass silage. Grass and Forage Science 44: 223-230.

Weinberg, Z.G., Chen, Y. \& Gamburg, M. 2004. The passage of lactic acid bacteria from silage in to rumen fluid, in vitro studies. Journal of Dairy Science 87: 3386-3397.

Wilkinson, J.M. \& Davies, D.R. 2013. The aerobic stability of silage: key findings and recent developments. Grass and Forage Science 68: 1-19.

Woolford, M.K. 1984. The silage fermentation. New York, USA: Marcel Dekker. 350 p. 